\title{
PENGARUH VARIETAS DAN PERBANDINGAN PELARUT PADA EKSTRAKSI MINYAK ATSIRI JAHE (Zingiber officinale Roscoe)
}

\author{
THE INFLUENCE OF VARIETY AND SOLVENT COMPARISON OF \\ GINGER (Zingiber officinale Roscoe) OIL EXTRACTION
}

\author{
Basito $^{1)}$ \\ 1) Jurusan Ilmu dan Teknologi Pangan, Fakultas Pertanian, Universitas Sebelas Maret, Surakarta
}

\begin{abstract}
Ginger (Zingiber officinale Roscoe) is agricultural commodity which is included in spice plant that has quite high value in social and economical. Ginger product has been become one of export commodity and as one of big nine spices which are traded in the world. The benefit of ginger oil is more less than ginger in using. Therefore, it will not influence to color. It also has higher economical value, longer shelf life and more practical. The experiment design of this research was group randomized designed. Ginger variety including variety of jahe emprit, jahe sunti and jahe gajah as group. Ratio of ginger and water in extraction which were consisted of 4 levels, they were ratio between material and water 1:10, 1:15, 1:20, 1:25 as treatment. Based on this research, the conclusion was ginger variety influenced to decreasing of cineol concentration refractive index and rendemen but this would not influence increasing of cineol concentration and specific gravity of ginger oil which was produced. According to chemical and physical parameter, the most optimal extraction was the extraction of variety of jahe emprit with water and ginger ratio 1:20 and ginger oil had water content 64,08\%, specific gravity 0,929 , refractive index 1,47 and rendemen $2,12 \%$.
\end{abstract}

Keywords : cineol concentration, ginger, refractive index, specific gravity, oil, rendemen

ABSTRAK

Jahe (Zingiber officinale Roscoe) termasuk komoditas pertanian berupa tanaman rempah yang mempunyai nilai sosial dan nilai ekonomis cukup tinggi. Produk jahe telah dijadikan salah satu komoditas ekspor, bahkan termasuk dalam sembilan besar rempah-rempah yang diperdagangkan di dunia. Kelebihan pengunaan minyak atsiri jahe dibanding jahe adalah pengunaan yang lebih sedikit sehingga akan semakin tidak mempengaruhi warna, mempunyai nilai ekonomis lebih tinggi dan mempunyai umur simpan lebih lama serta lebih praktis

Rancangan percobaan yang digunakan adalah Rancangan Acak Kelompok. Sebagai kelompok adalah varietas jahe meliputi, varietas jahe emprit, jahe sunti dan jahe gajah. Sebagai perlakuan adalah perbandingan jahe dan air dalam ekstraksi yang terdiri dari 4 level yaitu perbandingan bahan dan air 1: 10, 1: 15, 1: 20, 1: 25.

Berdasarkan penelitian disimpulkan bahwa varietas jahe berpengaruh terhadap penurunan kadar cineol, indeks bias dan rendemen tetapi tidak berpengaruh terhadap penurunan berat jenis minyak atsiri jahe yang dihasilkan. Perbandingan jahe:air yang semakin besar akan mempengaruhi kenaikkan indeks bias dan rendemen, namun tidak akan mempengaruhi kenaikan kadar cineol dan berat jenis minyak atsiri jahe yang dihasilkan. Dari parameter kimia dan fisik ekstraksi yang paling optimal terjadi dengan varietas jahe emprit dengan perbandingan air dan jahe 1:20 dan minyak atsiri jahe yang dihasilkan mempunyai kadar air $64,08 \%$, berat jenis 0.929 , indeks bias 1.47 dan rendemen $2,12 \%$.

Kata kunci : berat jenis, indeks bias, jahe, kadar cineol, minyak atsiri, rendemen

\section{PENDAHULUAN}

\section{Latar Belakang}

Minyak atsiri adalah senyawa mudah menguap yang tidak larut di dalam air yang berasal dari tanaman. Minyak atsiri dapat dipisahkan dari jaringan tanaman melalui proses destilasi. Pada proses ini jaringan tanaman dipanasi dengan air atau uap air. Minyak atsiri akan menguap dari jaringan bersama uap air yang terbentuk atau bersama uap air yang dilewatkan pada bahan.
Campuran uap air dan minyak atsiri dikondensasikan pada suatu saluran yang suhunya relatif rendah. Hasil kondensasi berupa campuran air dan minyak atsiri yang sangat mudah dipisahkan kerena kedua bahan tidak dapat saling melarutkan.

Jahe (Zingiber officinale Roscoe) termasuk salah satu komoditas pertanian berupa tanaman rempah yang mempunyai nilai sosial dan nilai ekonomis cukup tinggi. Produk jahe telah dijadikan salah satu komoditas ekspor, bahkan termasuk dalam 
sembilan (9) besar rempah-rempah yang diperdagangkan di dunia. Jahe setelah dipanen terus akan mengalami respirasi sehingga dalam penyimpanan sering mengalami kemunduran mutu.

Dewasa ini manusia semakin menyadari pentingnya waktu sehingga menghendaki segala sesuatu yang serba cepat. Hal tersebut juga terjadi dalam bidang menu makanan. Kebanyakan konsumen menghendaki produk makanan yang siap saji dalam sekejap. Hal tersebut mendorong tumbuhnya produksi makanan instan maupun kaleng (Anonim 2000). Untuk mendapatkan produk tersebut sangat membutuhkan bahan baku atau bahan tambahan lain misalnya jahe. Jahe untuk keperluan tersebut yang mempunyai nilai ekonomis adalah minyak atsiri. Minyak atsiri pada jahe dapat digunakan sebagai bahan kosmetik, bahan pemberi citarasa dan penghangat dalam beberapa produk minuman, permen dan kue.

\section{Perumusan Masalah}

Mengingat besarnya produksi serta permintaan ekspor produk jahe, dan mudah mengalami kemunduran mutu selama penyimpanan maka perlu dibuat minyak atsiri.

Permasalahannya, apakah konsetrasi pelarut dan beberapa varietas jahe berpengaruh terhadap minyak atsiri yang dihasilkan?

\section{Tujuan Penelitian}

Memberikan informasi kepada produsen tentang proses distilasi yang terbaik terutama dilihat dari varietas dan perbandingan pelarut.

\section{Manfaat Penelitian}

Hasil penelitian diharapkan dapat menjelaskan bagaimana proses destilasi minyak jahe dilihat dari varietas dan perbandingan pelarut untuk dapat menghasilkan minyak atsiri yang berkualitas baik, memenuhi standar yang ditetapkan oleh SII (Standar Industri Indonesia) serta mendapatkan rendemen yang tinggi. Sehingga dapat meningkatkan pendapatan rumah tangga petani

\section{METODOLOGI PENELITIAN}

\section{Bahan}

Bahan utama yang digunakan dalam penelitian ini adalah jahe varietas merah (jahe emprit), jahe sunti dan jahe gajah masing-masing sebanyak $15 \mathrm{~kg}$, serta bahan kimia lainnya sebagai reagen dalam analisa kimia, meliputi Resorsinol, alkohol $95 \%$, Petroleum Ether, aquades, dan lain-lain.

\section{Metode Penelitian}

Dalam penelitian ini akan digunakan tiga macam varietas jahe yang meliputi:

$$
\begin{aligned}
& \mathrm{Ve}=\text { Varietas jahe emprit } \\
& \mathrm{Vs}=\text { Varietas jahe sunti } \\
& \mathrm{Vg}=\text { Varietas jahe gajah }
\end{aligned}
$$

Sedangkan sebagai perlakuan adalah perbandingan jahe dan air dalam ekstraksi yang terdiri dari 4 level yaitu:

$\mathrm{R} 10=$ Perbandingan jahe dan air $1: 10$

$\mathrm{R}_{15}=$ Perbandingan jehe dan air $1: 15$

$\mathrm{R}_{20}=$ Perbandingan jahe dan air 1:20

$\mathrm{R}_{25}=$ Perbandingan jahe dan air 1:25

\section{Cara melakukan penelitian}

a. Ekstrasi minyak atsiri

Pengambilan minyak atsiri jahe dilakukan dengan mengunakan bahan pelarut air dengan perbandingan 1:10, 1:15, 1:20 dan 1:25. Pada volume $1000 \mathrm{ml}$ selama 2 jam pada tekanan $1 \mathrm{~atm}$ dengan pendingin air.

b. Pemisahan Minyak atsiri jahe

Minyak yang diperoleh dari hasil ekstraksi akan berada di atas permukaan sedangkan air akan berada di bawah. Pemisahan dilakukan dengan cara dimasukkan dalam corong pemisah. Skema diagram alir penelitian seperti Gambar 1.

\section{HASIL DAN PEMBAHASAN}

\section{Bahan Dasar}

Jahe yang digunakan sebagai bahan dasar dalam penelitian ini dilakukan analisis bahan dasar meliputi analisis kadar air dan kadar minyak atsiri. Hasil analisis kimia jahe segar dapat dilihat pada Tabel 1. 


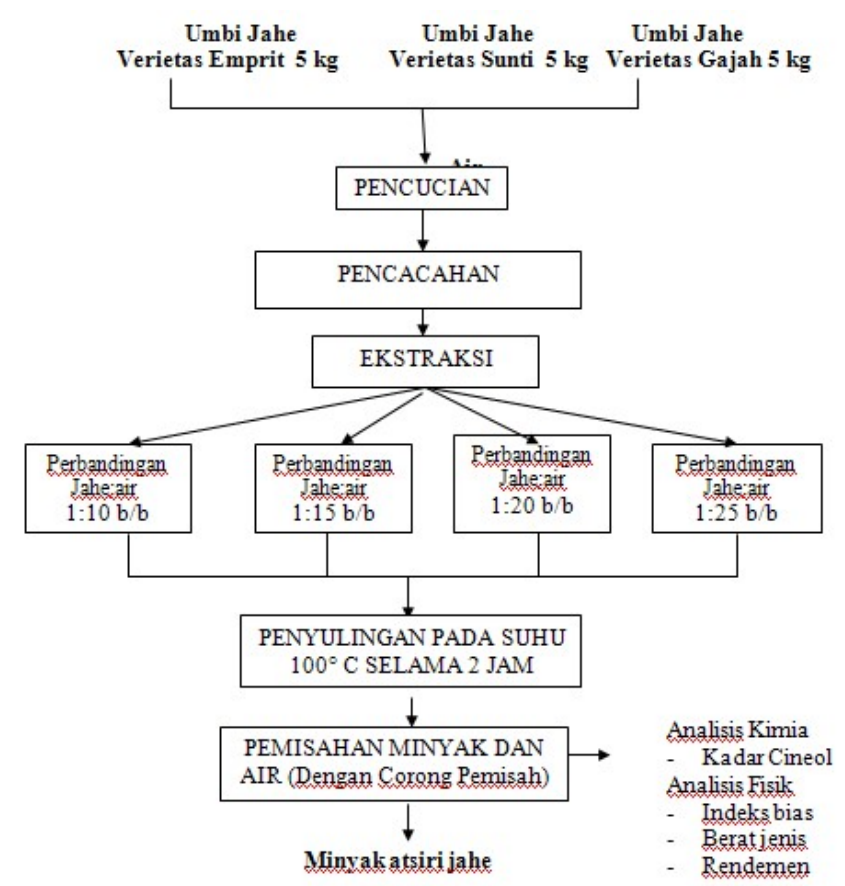

Gambar 1. Diagram Alir Penelitian

Tabel 1. Komposisi Kimia Jahe / 100 gram

\begin{tabular}{|l|c|c|c|}
\hline Kom-ponen & $\begin{array}{c}\text { Jahe } \\
\text { Emprit }\end{array}$ & $\begin{array}{c}\text { Jahe } \\
\text { Sunti }\end{array}$ & $\begin{array}{c}\text { Jahe } \\
\text { Gajah }\end{array}$ \\
\hline Air & 84.61 & 86.42 & 86.97 \\
Minyak Atsiri & 2.64 & 2.43 & 1.43 \\
\hline
\end{tabular}

\section{Minyak Atsiri}

Minyak atsiri yang dihasilkan dari beberapa perlakuan perbandingan air dan verietas jahe yang digunakan dilakukan analisis kimia dan fisik meliputi analisis kadar cineol, berat jenis, indeks bias dan rendemen.

\section{Kadar Cineol}

Cineol merupakan salah satu penyusun minyak atsiri pada jahe yang mempunyai nilai ekonomis disamping ester dari asam asetat serta zingeberol (Guether, 1952).

Perbedaan varietas jahe yang digunakan akan memberikan pengaruh sangat nyata terhadap kadar cineol minyak atsiri jahe, sedangkan perlakuan perbandingan antara jahe dan air tidak memberikan pengaruh yang nyata pada taraf signifikasi $1 \%$. Varietas jahe emprit akan mempunyai rerata kadar cineol yang paling tinggi yaitu $64,16 \%$, jahe verietas sunti $61,59 \%$, jahe gajah 55,85\%. Hal ini dimungkinkan adanya komposisi bahan dasar jahe antar varietas yang digunakan juga mempunyai kandungan cineol yang berbeda.

Perlakuan perbandingan jahe dan air yang semakin besar secara kuntitatif akan menghasilkan kadar cineol minyak atsiri jahe yang semakin besar. Hal ini dipengaruhi oleh semakin besar perbandingan air akan menaikkan kontak antara jahe dan air, sehingga akan menaikkan faktor tumbukan antar keduanya, sehingga jumlah cineol yang berhasil dikeluarkan dari jaringan akan semakin besar (Guenther, 1952). Pola perubahan kadar cineol selengkapnya dapat dilihat pada Gambar 2.

\section{Berat Jenis}

Berat jenis dimasukkan ke dalam peryaratan mutu minyak atsiri jahe berkaitan dengan kemungkinan adanya pengenceran

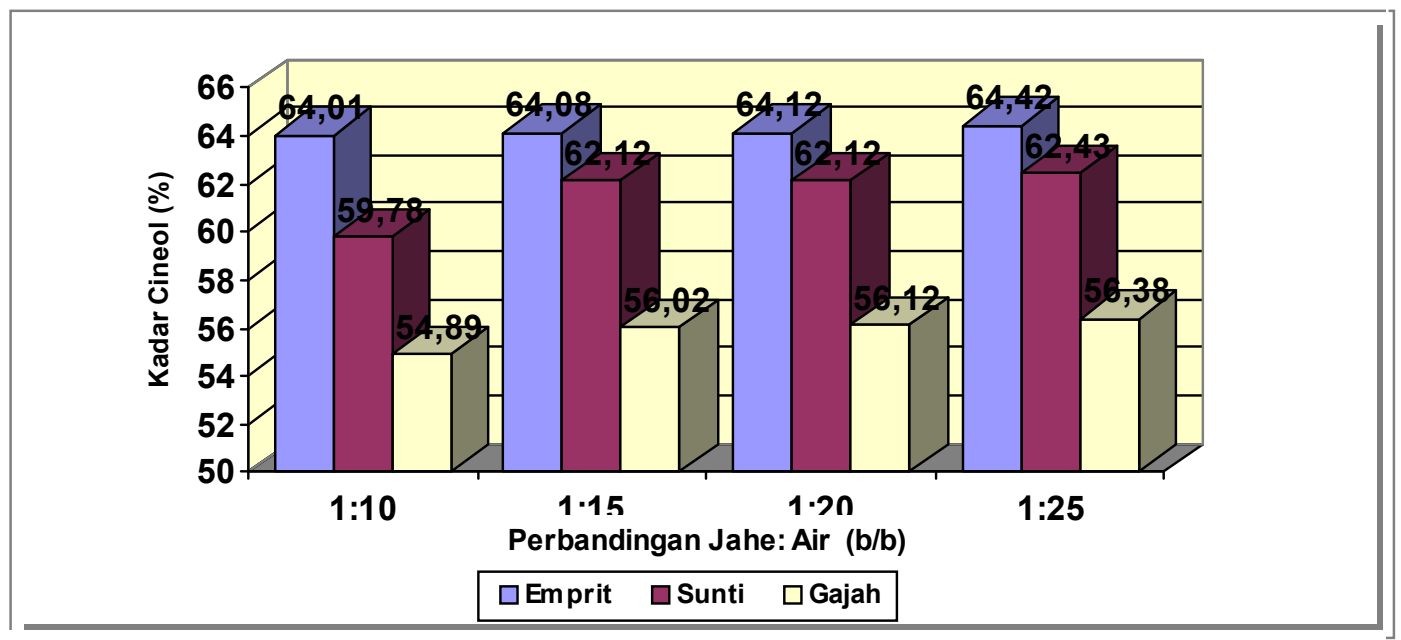

Gambar 2. Grafik Kadar Cineol Minyak Atsiri Jahe (\%) 


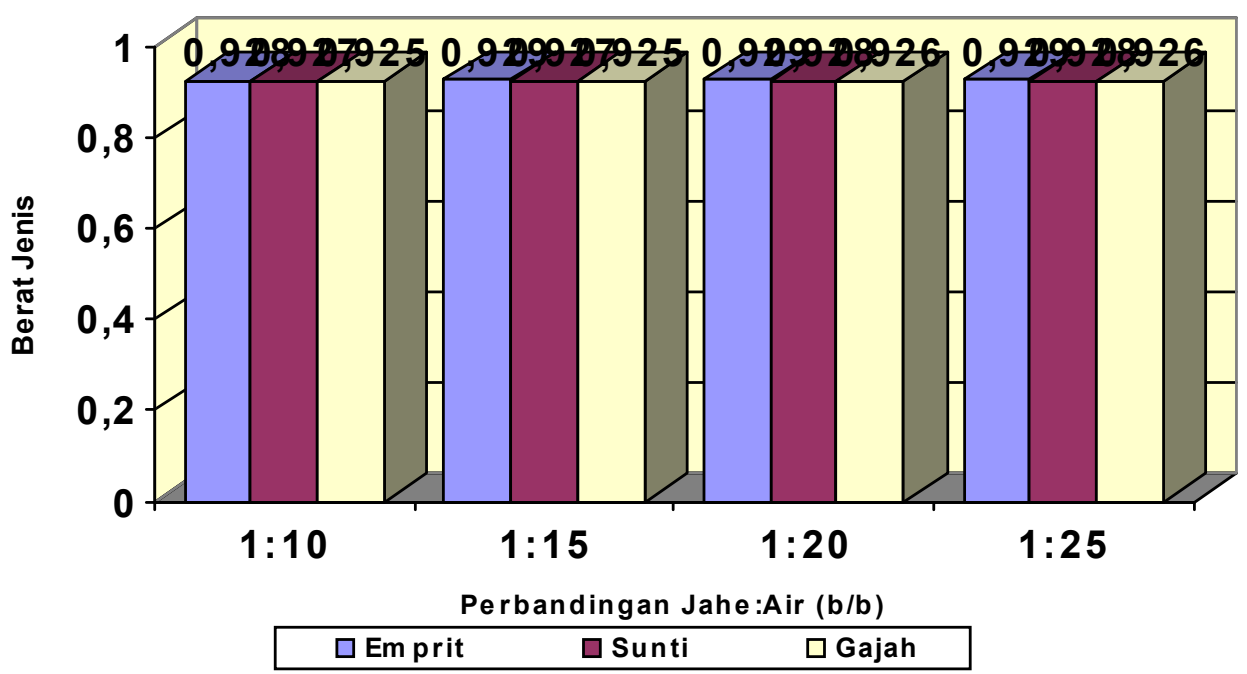

Gambar 3. Grafik Berat Jenis Minyak Atsiri Jahe

dengan bahan pelarut lain untuk menaikkan rendemen minyak atsiri. Dibawah 0,927 dimungkinkan minyak atsiri jahe tersebut sudah mengalami pengenceran, sedangkan jika jauh diatasnya kemungkinan dilakukan penambahan bahan padatan lain untuk menaikkan volume (Djoko Prayitno, 2000). Perbedaan varietas jahe yang digunakan tidak akan memberikan pengaruh terhadap berat jenis minyak atsiri jahe, sedangkan perlakuan perbandingan antara jahe dan air juga tidak memberikan pengaruh yang nyata pada taraf signifikasi 1\%. Varietas jahe emprit secara kuantitatif akan mempunyai rerata berat jenis yang paling besar, kemudian jahe varietas sunti dan terahir jahe gajah. Hal ini,disebabkan jahe emprit mempunyai kandungan ceniol yang lebih tinggi, dibanding verietas jahe lain yang digunakan.

Perlakuan perbandingan jahe dan air yang semakin besar secara kuntitatif akan menghasilkan berat jenis yang semakin besar. Hal ini dipengaruhi oleh semakin besar perbandingan air akan menaikkan kontak antara jahe dan air, sehingga faktor tumbukan antar keduanya meningkat. Kejadian ini akan menyebabkan lebih besar bahan yang dapat terpisahkan dari jahe dan menguap bersama dengan minyak atsiri, sehingga zat terlarut dalam minyak atsiri meningkat (Guenther, 1952). Pola perubahan berat jenis selengkapnya dapat dilihat pada Gambar 3.

\section{Indeks Bias}

Hasil analisis perbedaan varietas jahe yang digunakan akan memberikan pengaruh sangat nyata terhadap indeks bias minyak atsiri jahe, sedangkan perlakuan perbandingan antara air dan jahe juga memberikan pengaruh yang nyata pada taraf signifikasi 5\%. Varietas jahe emprit akan mempunyai rerata indeks bias yang paling tinggi yaitu 1,47, kemudian disusul varietas jahe verietas sunti 1,45 dan terahir varietas jahe gajah 1,40. Hal ini dimungkinkan karena komposisi bahan dasar jehe antar varietas yang digunakan berbeda.

Perlakuan perbandingan air dan jahe yang semakin besar akan menaikkan indeks bias minyak atsiri jahe yang dihasilkan. Hal ini dipengaruhi oleh semakin besar perbandingan air akan menaikkan jumlah senyawa yang larut di dalamnya terutama senyawa pembentuk warna yaitu vitamin C dan klorofil (Ketaren, 1985). Pola perubahan Indeks bias minyak atsiri jahe selengkapnya dapat dilihat pada Gambar 4.

\section{Rendemen}

Rendemen sering dikaitkan dengan tingkat efisiensi suatu proses produksi. Semakin tinggi rendemen suatu proses menandakan proses tersebut semakin baik (Yulianti, 1999). Hasil analisis perbedaan varietas jahe yang digunakan akan memberikan pengaruh sangat nyata terhadap rendemen minyak atsiri jahe, sedangkan perlakuan perbandingan antara jahe: air juga 


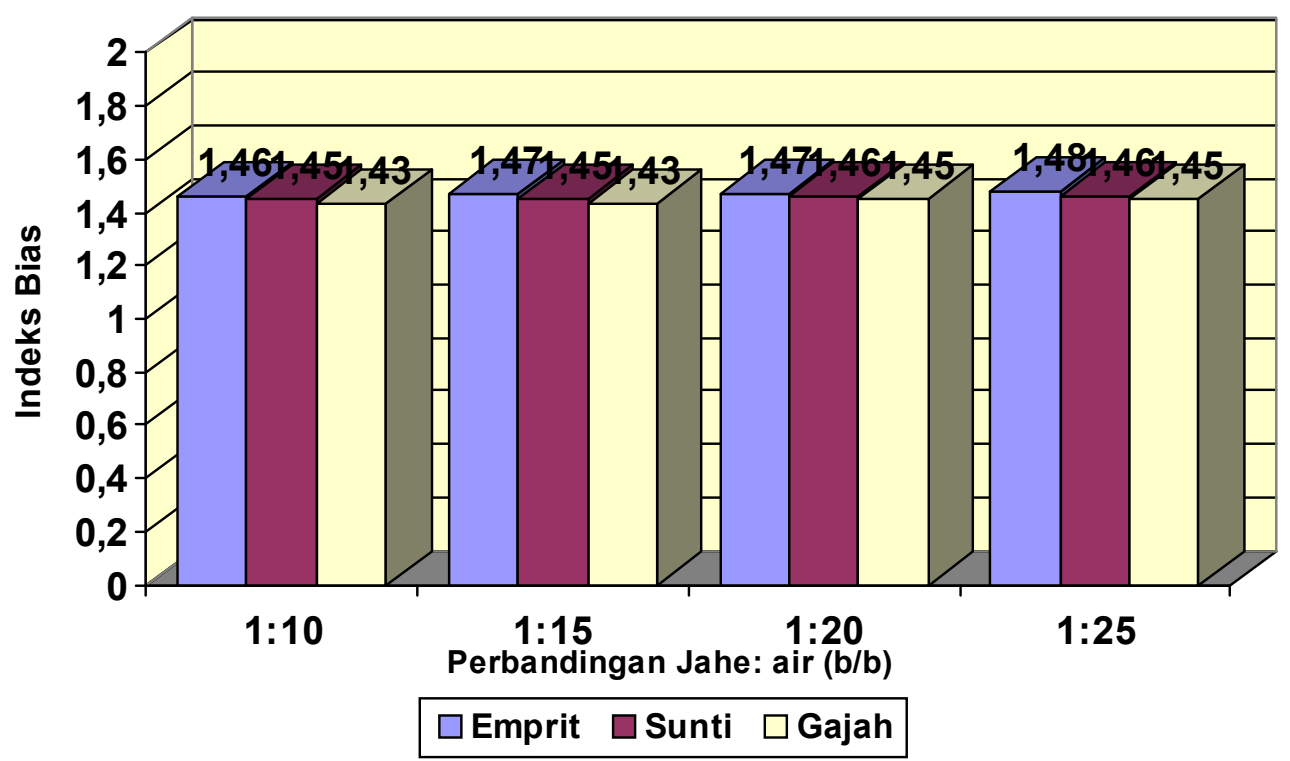

Gambar 4. Grafik Indeks Bias Minyak Atsiri Jahe

akan memberikan pengaruh yang nyata pada taraf signifikasi $1 \%$. Varietas jahe emprit akan mempunyai rerata rendemen yang paling tinggi yaitu $1,81 \%$, kemudian jahe verietas sunti $1,56 \%$ dan terahir jahe gajah $0,89 \%$. Hal ini kemungkinan terjadi karena kandungan minyak atsiri pada bahan dasar yang berbeda, sehingga dengan perlakuan yang sama jumlah minyak atsiri yang bethasil diekstrak juga akan berbeda.

Perlakuan perbandingan jahe:air yang semakin besar akan dihasilkan rendemen minyak atsiri jahe yang semakin besar. Hal ini dipengaruhi oleh semakin besar perbandingan air akan menaikkan kontak antara jahe dan air, sehingga akan menaikkan faktor tumbukan antar keduanya, sehingga jumlah minyak atsiri yang bisa dikeluarkan dari jaringan akan semakin besar (Guenther, 1952). Dari parameter rendemen ekstraksi yang paling baik pada jahe emprit dengan perbandingan 1:20. Dipilih 1:20 karena dengan 1:25 tidak memberikan hasil yang berbeda. Pola perubahan rendemen selengkapnya dapat dilihat pada Gambar 5.

\section{KESIMPULAN}

Dari hasil penelitian dapat disimpulkan sebagai berikut:

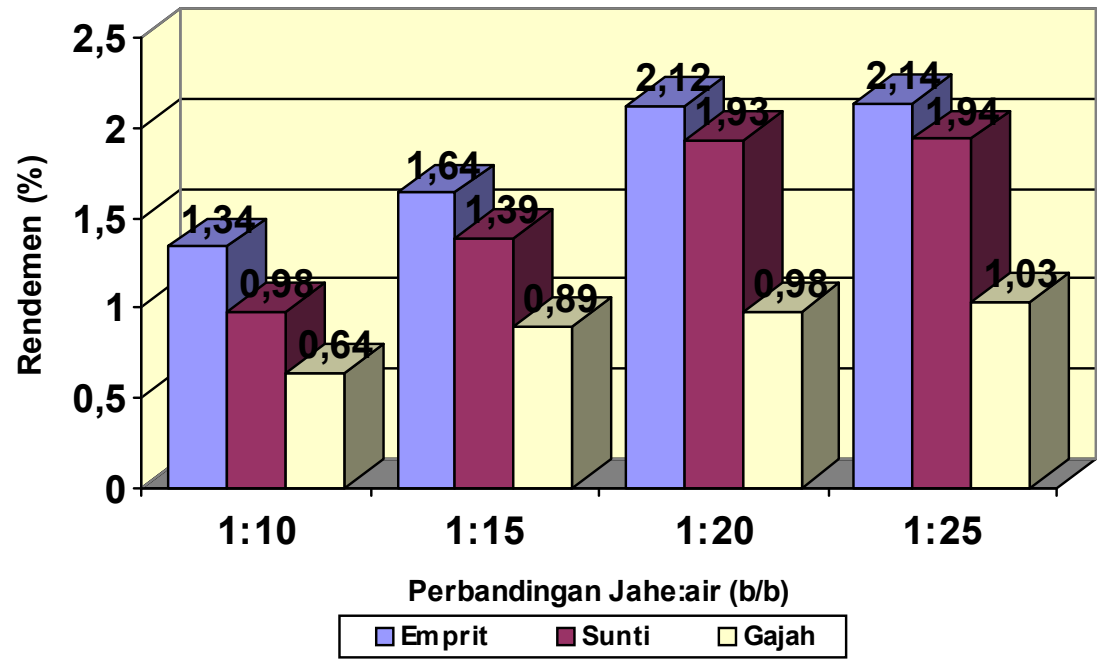

Gambar 5. Grafik Rendemen Minyak Atsiri Jahe (\%). 
1. Varietas jahe yang digunakan mempengaruhi penurunan kadar cineol, indeks bias dan rendemen namun tidak berpengaruh penurunan berat jenis minyak atsiri jahe yeng dihasilkan

2. Perbandingan jahe:air yang semakin besar akan mempengaruhi kenaikkan indeks bias dan rendemen, namun tidak akan mempengaruhi kenaikan kadar cineol dan berat jenis minyak atsiri jahe yang dihasilkan.

3. Dari parameter kimia dan fisik ekstraksi yang paling optimal terjadi dengan verietas jahe emprit dengan perbandingan jahe: air 1:20 karena minyak atsiri jahe yang dihasilkan mempunyai kadar air $64,08 \%$, berat jenis 0.929 , indeks bias 1.47 dan rendemen $2,12 \%$.

\section{DAFTAR PUSTAKA}

Anonim, 1967. Widya Karya Pangan Dan Gizi, Lembaga lmu pengetahuan Indonesia, Jakarta.

Anonim, 2000. Hasil Produksi Pertanian, BPS Yogyakarta.

Bressani R. 1965. The Use of Cottonseed Protein In Human Foods a.Food Technologi

Djoko Prayitno, 2002. Tanaman obat Dan Manfaatnya, IP2TP, Yogyakarta.

Guenther, E, 1952. The Esential Oil Vol I D Van Nostrand, London.

Jacobs. OR, 1988. Principles of Scence Marcel Dekker Inc, New, York.
Ketaren, S, 1986. Pengantar Minyak Dan Lemak Pangan. Universitas Indonesia, Jakarta

Kirk. RE. And DF Othmer , 1951. Encyclopedia of Chemical Technology Vol 14. The Interceince Encyclopedia Inc New York.

Martin . RE. G,J, Flick . DE. Hebard and DR War, 1982. Chemistry of Biochemistry of Martine Foot Produc., Avi Publishing Company.

Meyer, L.H, 1960. Food Chemistry. Rainhold Publishung Co., New York.

Rachmadi Lukman Rachim, 1990. Ekstraksi Minyak Biji Pepaya Dengan Pelarut Alkohol, Fakultas Teknik Kimia , AKPRIND, Yogyakarta.

Rahmat Rukmana, 1982. Budidaya dan Pasca Panen Tanaman Jahe. Kanisius, Yogyakarta.

Slamet Sudarmadji, Bambang Haryono, Suhardi 1989. Prosedur Analisa Bahan Makanan dan Pertanian, Edisi pertama, Liberty, Yogyakarta.

Somaatmadja, D, 1975. Minyak Atsiri Indonesia, Balai Penelitian Kimia, Bogor.

Supriyanto dan Supriyadi, 1992. Minyak Atsiri dan Rempah-rempah. Pusat Antar Universitas, Universitas Gadjah Mada, Yogyakarta.

Wibowo, D, 1987. Pengaruh Metode Distilasi Terhadap Rendemen Dan Mutu Minyak Kapulogo, Skripsi Fakultas Teknologi Pertanian, Universitas Gadjah Mada Yogyakarta. 